\title{
ARTICLES
}

\section{Incomes policy and the $1985-1986$ wage round: from non-market failure to market failure?}

\author{
Jonathan Boston*
}

Since the early 1970s New Zealand governments have relied heavily on non-market policy instruments (i.e. statutory contols, political pressure and moral suasion) to restrain the growth of wages and prices. The Labour Government has rejected this approach and is seeking to control inflation primarily through a reliance on market mechanisms. This article considers the merits of Labour's strategy in the wages arena. It is contended that there may be some significant transition costs associated with the new approach and that there is a risk that non-market failure will simply be replaced by market failure.

\section{Introduction}

One of the fundamental questions in the realm of political philosophy and political economy concerns the extent to which, and the spheres within which, the market should be replaced by the government (i.e. non-market modes of production, price setting and distribution). During the post-war period, the labour market has been at the centre of this debate. Essentially 2 opposing schools of thought can be identified.

On the one hand, there have been those, usually of a conservative ideological disposition, who have argued that wage determination should be left entirely to the market (Brittan and Lilley, 1977). The government's role, it is asserted, should be restricted to preserving property rights, ensuring that individuals and groups fulfil their contractual obligations, guaranteeing freedom of association, preventing the formation of producer monopolies, and outlawing certain restrictive, or socially harmful, labour market practices. In no circumstances, except perhaps with respect to its own employees, should the state be directly involved in pay fixing. Hence, in accordance with this approach, incomes policies of virtually any form, even including tripartite consultations of the kind currently in vogue in New Zealand, would be ruled out, either as a matter of principle or because of their expected harmful effects on economic efficiency, growth and employment.

On the other hand, there have been those, normally of a socialist or social democratic persuasion, who have contended that the determination of wages should not be left entirely to the forces of supply and demand. This view is based partly on the assumption that market outcomes will conflict with widely-held notions of distributive justice; but it is also based on the premise that free or unrestrained collective bargaining in the context of a highly unionised economy and a substantial degree of distributional dissent (i.e. conflict

\footnotetext{
* Lecturer, Department of Political Science, Canterbury University. This article is a revised and shortened version of a paper presented at an Institute of Policy Studies/Industrial Relations Centre Seminar on Incomes Policy and the Wage Round, 17 July 1985 at Victoria University of Wellington. Copies of the original paper are available from the author on request. I would like to thank all those who made comments on the paper, in particular the journal editor, the referees, Professor Gary Hawke and various staff members at Canterbury University.
} 
over income shares) will result in a socially unacceptable and economically inefficient level of unemployment (Flanagan, Soskice and Ulman, 1983; Layard, 1982; Meade, 1982). Since it would be both morally indefensible and politically impossible in a free society to abolish unions, or even to severely reduce their bargaining power, the only responsible solution lies in employing certain non-market mechanisms, firstly to restrain the use of union power, and secondly to ensure that the wage fixing system is structured in order to minimise the problem of externalities. In practical terms this has meant a commitment to some form of incomes policy, normally of a voluntary nature, and a preference for reasonably centralised pay fixing systems based on industrial, rather than occupational, bargain-
ing groups.

For much of the post-war era the latter school of thought has dominated the policymaking institutions of most OECD countries. Certainly this has been true in New Zealand (Boston, 1984). Indeed, few democratic countries have relied as heavily as New Zealand on non-market forms of wage and price control. For example, between March 1971 and July 1985 , a period of some $14 \frac{1}{4}$ years, statutory wage controls of one kind or another were in force for at least 9 years. Moreover, of the remaining 51/4 years, only 8 months can be legitimately regarded as a period of free collective bargaining (i.e. December 1972 August 1973). During the rest of the time governments sought by every means short of statutory intervention (moral suasion, political pressure, threats to re-introduce regulations, the offer of tax cuts, and so forth) to slow the growth of nominal wages.

The fact that New Zealand's economic performance has been relatively poor since the mid-1970s, especially with respect to inflation and the growth of output and employment, has prompted many observers to conclude that this protracted attempt to restrain wages and prices through non-market instruments has been a dismal failure (Treasury, 1984; choice but to . Partly on the basis of such a judgement, it is contended that we have no and price control. Unless we do upon more orthodox market-orientated forms of wage relative wages will fail to adjust properly to changing ideas, attitudes and working tries, and unemploymoring practices will continue to pervade our manufacturing indus-

At the risk of some will remain at unnece

tion", which is now fa oversimplification, it can be argued that the "more-market soluing basic elements:

(i) a sole dependence on monetary and fiscal policies to restore price stability;

(ii) an assumption that the adjustment costs associated with a disinflationary strategy can be substantially lowered by convincing the market that supply shocks (both
wage and non-wage) will not be accommodated;

(iii) a rejection of all formal, explicit incomes policies, including wage guidelines and comprehensive price controls;

(iv) a determination to weaken the organisational strength of the union movement by curbing the closed shop, preventing secondary picketing, and making strikes

(v) measures to increase the responsiveness of wages to market forces by decentralising the pay fixing system in both the private the public sectors, curbing job security provisions, cutting unemployment benefits, lowering (or removing entirely) minimum wage provisions, and reducing the importance of historic relativities and coercive comparisons in wage bargaining; and

(vi) measures to deregulate other markets, foreign exchange markets, capital markets and product markets, where deemed desirable.

This is by no means an exhaustive list. Nor have the items been listed in a descending order of importance. Moreover, it must be acknowledged that the Labour Government in New Zealand is not committed to all aspects of this neo-conservative policy package. of point (v), and has not het rumpletely rejected point (iv), is ill-disposed to many aspects same time, however, the rover out wage guidelines or selective price controls. At the keen to "free-up" the wage fixing system, endorses points (i), (ii) and (vi), and is also 
place bargaining, reducing the importance and coverage of national awards, and ensuring that arguments based on relativities do not dominate the bargaining process to the same extent as they have in the past.

This shift to a market-orientated policy stance by many OECD governments since the late 1970 s raises many important questions: How are we to account for the disintegration of the previous policy consensus, founded, at least in part, on Keynesian assumptions? How are we to explain the fact that Labour Governments in both Australia and New Zealand are pursuing very similar policies to the Conservative Administrations in Britain and Norway? Why is it that the Australian Labour Government has opted to reinstate a centralised wage fixing system - based on the Conciliation and Arbitration Commission and 6-monthly cost of living adjustments - wheras the Labour Government here has chosen the path to a more decentralised system? And perhaps most important of all, what are the prospects of the more-market approach in New Zealand achieving its claimed advantages? In particular, will the attempt to restrain wages and prices primarily through the forces of supply and demand (i.e. in the context of a firm, non-accommodating monetary policy) work in the manner desired, or will non-market failure simply be replaced by market failure? To put it more bluntly, will the next year or so witness a wage explosion with all the associated negative consequences? It is obviously not possible in a short article to explore such issues in any depth. The intention, therefore, is to focus on a limited range of subjects, namely, the validity of the credibility hypothesis, some of the advantages and disadvantages of the planned move to a more fragmented and less relativity-driven pay fixing system, the prospects for the 1985/86 wage round, and the Government's options in the event of an excessive rise in money wages.

\section{Monetary policy and the credibility hypothesis}

Two theoretical propositions, usually associated with the monetarist school of thought, lie at the heart of the Labour Government's counter-inflation strategy. Both are controversial in character. The first proposition asserts that control of the money supply is both a necessary and a sufficient condition for the attainment of price stability. Hence, in accordance with this view, it is contended that as long as the Government pursues a stable, firm, predictable and non-accommodating monetary policy, the domestic rate of inflation - after a certain lag - will be brought down to an acceptable level (i.e. a level roughly consistent with those of New Zealand's major trading partners). The second proposition, which is often referred to as the credibility hypothesis, can be stated as follows: the greater the credibility with which a government's counter-inflation policy is viewed by price setters, the faster the adjustment of wages and prices, and the smaller the costs - in terms of lost output and employment - of a disinflationary monetary policy (Cagan and Fellner, 1983; Kozomzay, 1982; Perry, 1983; Taylor, 1982).

How valid is the first proposition? The evidence tends to support the assertion that inflation can be controlled, at least in the medium-to-long term, by means of a firm monetary policy. Having said this, however, it should be noted immediately that for some countries there appear to be very considerable adjustment costs associated with a reliance solely on traditional policy instruments (Buiter and Miller, 1983). Moreover, control of the money supply is neither a sufficient, nor even a necessary, condition for restraining wage and price inflation in the short term (i.e. between 1-2 years).

The second proposition, the credibility hypothesis, is open to very serious doubt. In the first place, if a government's economic strategy is to be deemed "credible", certain highly restrictive conditions must be satisfied. In practice it is improbable that they will be. In the second place, even in the unlikely event that a government's economic strategy is perceived by all the decisive actors in the economy to be credible, this will not be sufficient to ensure that wages and prices adjust in the manner, or with the speed, intended. Thus, the transition costs often associated with a so-called "orthodox" disinflationary strategy will not necessarily be reduced significantly, let alone avoided entirely, 


\title{
68 Jonathan Boston
}

by the mere attainment of "policy credibility".

In analysing the credibility hypothesis it is useful, as Kozomzay (1982) has pointed out, to distinguish between 3 separate kinds of credibility. To start with, there is the question of whether a government's economic policies are credible in themselves. That is to say, are there grounds for believing that the policies being implemented are logically consistent, sensible, plausible and directed towards the government's chosen ends? Next, there is the question of whether a government can be relied upon to pursue its stated policies with consistency, resolution and perseverence, notwithstanding any adverse shortterm political and economic consequences? Lastly, there is the matter of whether a government can be regarded as credible? Can it reasonably be assumed, for instance, that those in power will survive for a sufficient length of time to see their policies fully implemented and brought to fruition? While it can be argued that the desired behavioural response is in some sense dependent on all 3 kinds of "credibility" being realised, for our present purposes the most relevant category is the second, namely, whether a government can be trusted to stick to its declared strategy come what may.

As noted earlier, the Labour Government and its economic advisers are committed to reducing the current rate of inflation and plan to achieve this objective by exerting strict control over the money supply. To quote from the Treasury's briefing paper to the 1985 Tripartite Wage Conference (TWC):

\begin{abstract}
Monetary policy will suport a steady reduction in the rate of inflation .... The liquidity base is being managed so as to substantially reduce the growth in nominal (as opposed to real) national income over the next few years . . . Although it is difficult to be precise, the current policy setting is likely to be consistent with nominal growth in national income in the order of 10-13 percent in 1985/86, falling to around 7-9 percent in 1986/87 (Treasury, 1985B, p. 3 and p. 13).
\end{abstract}

One obvious question prompted by this approach is how the reduced growth in nominal national income will be "split" between prices and quantities. That is to say, will the inflation rate exceed the Government's nominal income target, thereby choking off growth in real output and employment, or will the inflation rate decline steadily, as intended, thereby enabling economic growth to continue, albeit at a slower pace? In short, will there be significant adjustment costs?

The Treasury, for one, acknowledges that such matters are "difficult . . . to judge" (Treasury, 1985B, p. 13). Nevertheless, invoking the credibility hypothesis, the Treasury argues that much "will depend on the degree of confidence the private sector has in the current policy being maintained ..." (Treasury, 1985B, p. 13). What this means is that if it is known in advance that the Government is determined not to ratify or accommodate wage and price increases above a certain level, and if it is widely believed that the Government will not alter course in the face of a pay explosion, then wage negotiators (and other price setters) are much less likely to press for unacceptably large increases. This being so, the rate of inflation will be held in check and there will be reasonable scope for a growth in output and employment.

More specifically, the credibility of a non-accommodating monetary policy is thought to "work", in the sense of making the short-run Phillip's Curve steeper and hence lowering the transition costs of a disinflationary policy, through at least 3 separate, but equally direct, mechanisms. To start with, the more credible a government's monetary policy is believed to be, the more rapidly it is thought that inflationary expectations will adjust downwards. Thus, for example, it is argued that if union negotiators expect the rate of inflation to fall during the currency of their forthcoming settlements, they will agree to smaller money-wage deals. If this behavioural response is more or less universal, then the rate of wage inflation will fall and in due course there will be further downward pressure on the rate of price inflation.

Another mechanism through which policy credibility is expected to work is by convincing workers of the negative consequences which will result from excessive wage increases. In other words, it is contended that if union negotiators are certain that the 
Government will stick firmly to its non-accommodating economic strategy, and if they wish to preserve existing employment levels (which it is assumed they do), they, will not take the risk of pressing big wage claims. In a similar fashion it is asserted that policy credibility will increase the resistance of employers to excessive wage demands. This is because firms will recognise that if there is a large increase in their labour costs, they may have to contend with a significant fall in demand for their products, a decline in profitability, and possibly severe liquidity problems (Douglas, 1985, p. 10).

\section{A brief critique}

The credibility hypothesis is unlikely to operate as intended unless (a) there is a relatively low level of distributional dissent and bargaining intensity; (b) there is a reasonable degree of consensus amongst the decisive actors in the economy about the merits and likely consequences of the Government's economic strategy; (c) the wage fixing system is sufficiently centralised to permit the co-ordination of pay claims and settlements, and (d) the union movement is committed to full employment, or more importantly, places employment objectives ahead of real-wage objectives. It would seem that few, if any, of these conditions are satisfied in New Zealand at the moment. Nor is there much prospect that they will be in the future.

It is not hard to illustrate the difficulty of both establishing the necessary degree of policy credibility and ensuring that wage bargaining (and other price setting) behaviour is altered in the manner intended. For example, for a union to reduce its bargaining intensity or change its preferences in accordance with the dictates of the credibility hypothesis, the following conditions would have to apply:

(1) the union negotiators in question must be confident that the government can control the money supply;

(2) the union negotiators must believe further that the government will control the money supply and adopt a non-accommodating strategy regardless of any supply shocks (wage or non-wage) with which it is confronted;

(3) the union negotiators must accept the government's basic theoretical presuppositions to the effect that (a) as a result of conditions (1) and (2) the rate of price inflation will fall and (b) in the context of conditions (1) and (2) a high average level of wage settlements will result, sooner or later, in higher unemployment and lower real output growth;

(4) the union negotiators must believe that there is a strong probability that some of their members will face unemployment if they press for a wage rise which is deemed, in the light of the government's announced monetary rule or target, to be excessive;

(5) finally, the union negotiators must place more weight on the preservation of their members' jobs than on the pursuit of other objectives: higher real wages, restored relativity relationships, improved working conditions, higher non-wage benefits and so forth.

It is conceivable that some wage negotiators may endorse all these propositions. It is also conceivable that all negotiators may accept one or 2 of them. However, it is most improbable that even a slim majority of negotiators would give consent to all 5 propositions. And in a wage bargaining system such as that of New Zealand's, where so much still depends on trend-setting awards and historic relativities, it would only take a few important bargaining groups to reject some aspect of the credibility hypothesis for the approach to be rendered ineffective as a means for reducing the adjustment cost of a disinflationary strategy. Let us explore the 5 conditions in greater depth.

\section{Condition 1}

Although few economists would dispute the view that governments should seek to 
exert a measure of control over the main monetary aggregates and pursue consistent macroeconomic policies, the experience of a number of countries would suggest that this can be a good deal more difficult than some optimists (and monetarist hardliners) might lead one to believe. For example, the Fraser Government in Australia, despite some initial success in 1977-78, completely failed during the late 1970s and early 1980 s to achieve its planned reductions in monetary growth (Jones, 1983). Likewise, the Thatcher Government in Britain, which can hardly be accused of lacking the necessary political will, found it much harder than anticipated to reduce the growth of the money supply during its first term of office. For example, in the 4 years to March 1984 the cumulative increase in M3 (the Government's main money measure) was virtually double the Treasury's original target announced in March 1980 (Davies, 1985, p. 13). One cannot but wonder, in the light of such experiences, whether the New Zealand Treasury's nominal national income targets for 1985-86 (10-13 percent) and 1986-87 (7-9 percent) will be found similarly wanting, albeit by a much smaller margin of error than the British results. And, if these doubts are shared by a significant number of economic agents, what consequences will this have for the credibility of Labour's disinflationary strategy?

\section{Condition 2}

Some economists have suggested that the simple announcement of the government's intention to pursue a firm monetary policy is all that is required to lower inflationary expectations, and hence reduce money-wage targets. However, as Taylor (1982, p. 81) argues, the mere declaration by someone of their intention to do something is by no means sufficient to convince others that they will actually do it, especially when what the person is threatening to do may entail considerable costs. In order to establish policy credibility, therefore, further conditions must be satisfied. For example, one would want to know whether the person in question (or in this case the Labour Government) had kept previous promises of a similar kind (or had fulfilled similar threats), whether there was likely to be some element of bluff involved, whether the person's will to pursue the policy was likely to falter if the costs were found to be much higher than expected, and so forth.

Applying this reasoning to the case of a government's monetary policy, it may well be that credibility will not be attained, at least to the extent desired by policy makers, until the government is actually faced with supply shocks and rising unemployment and refuses to reflate. Yet if this is so, it means that the experience of a prolonged recession may be a necessary condition for establishing credibility. There are 2 obvious drawbacks with such a conclusion. On the one hand, if a government's threats, namely, to allow unemployment to rise unchecked if wage and price setters fail to exercise the appropriate degree of restraint, are only taken seriously when unemployment actually begins to bite, then the threat must be deemed to have failed. On the other hand, as Perry (1983, p. 601) notes, once a recession is well advanced it will be difficult, if not impossible, to distinguish analytically between the respective effects of credibility and austerity on price fixing behaviour. In fact, it may be austerity which eventually achieves the policy objectives (i.e. a fall in the rates of wage and price inflation) with credibility making no independent contribution.

In this context it is interesting to observe the Treasury view, expressed twice in the briefing paper for the 1985 TWC, that "current expectations relating to future demand and inflation seem much higher than can be justified by present policies" (Treasury, 1985B, p. 17). It is unclear by what method Treasury has sought to measure "current expectations", but assuming that this judgement is correct it indicates that "the market" is either not convinced that Labour will stick to its present policies regardless of their consequences for output and employment, or that it doubts that the Government's policies will have their intended effects. Whichever happens to be the case, policy makers may have to devise new ways of altering market perceptions if their policy objectives are to be secured in a relatively painless manner. 


\section{Condition 3}

It is possible, of course, that no amount of sabre rattling (or the hoisting of monetary targets) will make much difference to inflationary expectations or wage bargaining behaviour, either because many significant actors in the economy do not share the Government's world view or because there are other powerful, countervailing social, institutional and economic forces at work. For example, some union leaders may reject, for a whole host of theoretical and ideological reasons, the assumption that controlling the money supply will lower the rate of inflation and/or the assumption that there is a trade-off between real wages and employment (both in general and in their own particular case). And as Schelling (1982, pp. 78-79) has argued, without a consensus on theoretical propositions, the credibility hypothesis would appear doomed.

No doubt interested observers will differ in their assessment of the extent to which wage negotiators in New Zealand understand and endorse the economic theories underpinning Labour's current policy stance. There can be little question, however, that many economic agents, especially within the union movement, hold serious reservations about certain crucial aspects of the Government's strategy and that unlike some other countries, such as Austria and Sweden, the major parties involved in wage determination do not share an agreed theory (be it monetarist, post-Keynesian, institutionalist or Marxist) about the determinants of economic behaviour. Nor is there much hope that such a consensus can be established.

Of course, even if there was broad agreement on the fundamentals of macroeconomics, this would not be sufficient to guarantee a painless process of disinflation. After all, union wage negotiators may accept that a tight monetary policy will reduce inflation and may accordingly revise their inflationary expectations downwards, but this will not necessarily lead them to alter their money-wage targets. This is because their view about the future path of inflation is only one of a whole range of factors (rank-and-file pressures, relativity concerns, real-wage catch up, the tax structure, fiscal drag, political considerations, etc.) which influence the formulation and pursuit of wage claims. Thus, union negotiators may still press for sizeable pay increases even in the face of declining inflation and lower inflationary expectations.

\section{Condition 4}

But, it may be objected, surely union negotiators will be aware that if they demand wage rises which are inconsistent with the government's monetary rule some of their members may face redundancy. Surely this threat of unemployment will be sufficient to alter pay-fixing behaviour. Leaving aside the problem which wage negotiators virtually always encounter in an uncertain world, namely of determining the actual level of money-wage increases which is consistent with the maintenance of existing employment levels (in the relevant firm, industry or occupational category), it cannot be assumed that the threat of unemployment will have a decisive impact on the nature of union wage claims or the level of bargaining intensity. There are 2 main reasons for this.

First, in a decentralised bargaining system, union negotiators and their constituents may take the view that any harmful consequences resulting from a high wage settlement can be largely externalised, that is, passed on to others, perhaps those just entering the labour market or those in the non-unionised sector of the economy (Llewellyn, 1980, p. 51). In short, they may assume that they will suffer no direct adverse repercussions by pursuing a big wage claim. Alternatively they may conclude that the risks are worth taking. Employers may also adopt a similar kind of reasoning. As the Employers' Federation notes in its statement to the TWC on 12 June 1985:

. it is possible that some firms will be willing to risk the dangers posed in general by monetary policy, in the hope that the eventual impact will be felt elsewhere. Trade 


\section{Jonathan Boston}

unions may press them to adopt just such a strategy (New Zealand Employers' Federation, 1985, p. 7).

Only in a highly centralised system of wage bargaining, such as exists in Austria, does there seem much hope of overcoming this kind of collective action problem or Prisoner's Dilemma.

\section{Condition 5}

The other reason why the threat of unemployment may be an inadequate deterrent is as follows: union negotiators, especially in a decentralised bargaining system, know from experience that a big wage rise means an immediate increase in real disposable income for their members, whereas any unemployment which may occur as a result will not be felt for some time. Assuming positive time preferences, unions may prefer higher real wages now, even at the expense of future unemployment and the possibility of slower real-wage growth in the medium term. Alternatively, they may decide that the improvements in their real (or relative) wages are worth the expected sacrifices in terms of the reduced security of employment. Such reasoning is all the more likely when labour market conditions are relatively buoyant, as is currently the case in New Zealand.

To sum up, there is a variety of reasons, the absence of a broad economic consensus, doubts about a government's resolve, and uncertainty over employment prospects, why policy credibility may be difficult to establish. Moreover, even if a government's monetary policy is universally held to be credible, this will not guarantee a swift or painless reduction in the rate of inflation. Such conclusions are now accepted by economists representing a wide range of intellectual traditions. For example, Perry points out that the reduction in inflation which occurred in many countries during the early 1980s "was not exceptionally prompt, and when wages finally did slow by unusually large amounts ... that development was accompanied by unusually large declines in employment" (Perry, 1983 p. 600).

The British experience is perhaps the most graphic in this respect (Buiter and Miller, 1983). In spite of the Thatcher Government's repeated declarations after coming to office in May 1979 that it would not accommodate excessive wage and price increases, pay negotiators appear to have taken little notice. Indeed, rather than reducing their settlement levels as intended by the Government, unions pressed for even larger pay deals. The result, in short, was that the annual rate of change in average earnings accelerated from 13.4 percent at the end of the second quarter of 1979 to a peak of 22.2 percent by the third quarter of 1980 . It was only with the dramatic fall in profitability and output during 1980-81, and the resultant collapse in employment in the manufacturing sector, that wage inflation began to decline. As New Zealand embarks on its own attempt to slow inflation from its current rate of nearly 17 percent by means of monetary and fiscal instruments, such experiences are well worth pondering.

\section{Wage fixing: Is there an optimal system?}

It has been common during the past few decades for industrial relations practitioners and specialists in most countries to express dissatisfaction with their system of wage determination and to search for a better (i.e. more socially and economically efficient) system. From the 1950s to the early 1970s, for example, many American practitioners, frustrated by both the high level of strike activity and nominal wage rigidity which characterised their decentralised bargaining system, tended to gaze longingly across the Atlantic at the relatively strike-free, centralised wage fixing systems of Scandinavia, the Netherlands, West Germany and Austria. Since the early 1980s, however, the position has been virtually reversed. It is now the turn of European policymakers to be disgruntled. 
With their employment objectives apparently thwarted by a high degree of real-wage rigidity and inflexible relative wages, and with industrial unrest growing, especially in Britain, Denmark, Sweden and West Germany, many governments in Europe are trying to refashion their industrial relations systems more along American, and to a lesser extent Japanese, lines. In short, they are seeking to make wages more responsive to market forces by reducing union coverage, removing unions' legal privileges, changing payment systems, cutting various social security provisions, decentralising public sector pay fixing and reducing minimum wages.

What is one to make of this quest for greater wage flexibility? Are decentralised bargaining systems necessarily superior to centralised ones? And, what are some of the transition costs which may be encountered in attempting to reform New Zealand's wage fixing system?

Before proceeding further some clarification of the terms "centralised" and "decentralised" is required. According to Tarantelli:

\begin{abstract}
a centralised system of industrial relations is a system where wage contract renewals (and more generally, contract renewals determining labour costs) mainly take place at the national and/or industrial or regional level, rather than at company and plant level. Further, it is a system where a few contract renewals influence directly (e.g. through the so-called negative coalition right) or indirectly (e.g. through pattern bargaining) a high percentage of the labour force. It is also a system where contract renewals tend to take place at close (e.g. one-year) and non-overlapping intervals (e.g. synchronous) (Tarantelli, 1983, p. 50).
\end{abstract}

If these are the main features of a centralised system, it follows that a decentralised system will be one in which rates of pay are determined primarily through settlements at the enterprise level, in which there are no dominant trend-setting contracts, and in which there are no systematic attempts by employers or unions to co-ordinate the magnitude and timing of pay settlements.

In terms of Tarantelli's definition, New Zealand's wage fixing system must be regarded as reasonably centralised. Most workers have their rates of pay set at the national or industry level and there are a number of key trend-setting wage contracts (e.g. the Metal Trades Award, the General Drivers Award and the Electrical Contractors Award) which set the "going rate" for most other national awards. At the same time, second-tier bargaining (e.g. "house" agreements at the company and plant level) has become increasingly important in certain parts of the country since the mid-1960s, and, if anything, this trend has accelerated during the past year. Furthermore, in contrast to the central organisations of labour and capital in Sweden and Austria, both the FOL and the Employers' Federation are relatively weak in terms of their constitutional authority and coercive resources. The other point to note is that, despite the small size of the nation's workforce and despite the fact that bargaining occurs largely at a national level, there are well over 1000 separate awards, voluntary settlement collective agreements and house agreements. Given these considerations, therefore, it would be wrong to exaggerate the centralisation of the wage fixing process in New Zealand.

It is difficult to assess the relative merits of the various industrial relations systems that are available. According to neo-classical economic theory, decentralised bargaining at the plant or enterprise level should be the preferred option on efficiency grounds. Under such a system, or so the argument goes, wages will be reasonably responsive to market forces (i.e. skill shortages, company profitability and productivity improvements). Hence, if there is an excess supply of suitable labour, wage rates will fall (or at least they will rise more slowly than other rates). Likewise, if there is a shortage of particular skills, the wages of the relevant skill categories will rise (or fringe benefits will be improved, or higher overtime rates will be paid). In this way the labour market will clear, albeit after a certain time lag, and involuntary unemployment will be minimised.

It is evident that both the Labour Government and its economic advisers hold to such assumptions. For instance, the Prime Minister, Mr Lange, has described the present New 
Zealand system of wage fixing as a "rigid, horribly overcentralised structure" (National Business Review, 1 July 1985, p. 6). Similar sentiments are to be found in the 1985 budget, the Treasury's briefing paper for the 1985 Tripartite Wage Conference and in Economic Management.

If a neo-classical prescription for the labour market is to be followed in New Zealand, a variety of reforms would be required. These could include:

(1) lowering the "reservation" wage (i.e. the wage below which someone will choose not to work) and hence making low paid jobs more attractive (e.g. by reducing the level of unemployment benefits and other social security provisions);

(2) reducing minimum award rates where there is an over-supply of labour;

(3) removing the blanket coverage provision from national awards;

(4) altering payment systems (e.g. the widespread introduction of profit sharing as suggested by Weitzman [1985]);

(5) reorganising the trade union movement and bargaining units along industry and enterprise lines;

(6) restructuring the system of public sector pay fixing to make it more responsive to market forces (e.g. abolishing the annual general adjustment, imposing cash limits, etc.); and

(7) removing various other labour market rigidities, such as barriers to occupational entry, restrictive working practices, barriers to geographical mobility, inadequate training opportunities, and so forth.

According to its proponents, such a strategy would, if pursued with vigour, bring the following results. There would be a significant decline in the importance of occupationallybased minimum-rate documents. The multi-tier system of pay settlements would be replaced eventually by a unified, single-tier system. Individual employers would no longer have to contend with a multiplicity of bargaining groups, nor with demarcation disputes. The importance of the present trend-setting pay negotiations would diminish considerably. Attempts to coordinate wage contracts by means of guidelines or the synchronising of settlement dates would be rendered unnecessary. And ability to pay criteria would replace the current emphasis on horizontal relativities. In theory, all this could be expected to greatly enhance the efficiency of the labour market. Relative wages would adjust promptly to changing market conditions. There would be greater incentives for effort and experience. Unemployment would be reduced. And, as the economy expanded and productivity improved, the average level of real wages would rise.

How realistic is such a scenario? One of the principal weaknesses of the neo-classical paradigm is that it downplays, or else completely disregards, a whole host of political, ideological, institutional and sociological forces. Thus, such matters as the concentration of organistional power in labour and product markets and the variability of bargaining intensity are often deemed to be of little importance. Similarly, no consideration is given to sociological phenomena like class antagonism, group dynamics, distributional dissent, competition for "positional" goods, feelings of relative deprivation and conflicting notions of social justice. In a world without unions, employer associations, power, coercive comparisons, the interdependence of preferences, bargaining tactics, leadership discretion, variable work effort, group solidarity and ideological conflicts it is just possible that labour markets could be made to operate in accordance with neo-classical or new classical assumptions (i.e. rational, atomistic, competitive and instantaneously-clearing). But such a world does not exist. Nor can it be brought into being.

The question, then, is whether a decentralised market-orientated bargaining system is still the "optimal solution" given the inevitable "distortions" and "imperfections" with which we must contend. The answer here, as Robert Gordon (1982) observes, is by no means self-evident. Indeed, it is doubtful whether there is such a thing as an "optimal solution". Perhaps the most that can be said is that the available empirical evidence sug. gests (but in no way proves) that a degree of centralisation (e.g. by means of synchronised wage rounds, trend-setter awards, or hierarchically structured, authoritative peak organisations of labour and capital) is preferable to a highly fragmented bargaining system. For 
example, as various writers have noted (McCallum, 1983; Schmidt, 1984; Tarantelli, 1983), countries like the United States, Canada and the United Kingdom, which have reasonably decentralised bargaining systems, have generally experienced higher levels of strike activity and greater unemployment than countries such as Norway, Sweden and Austria where wage determination is more centralised. There are, of course, some exceptions to this rule. Switzerland, for example, has a decentralised bargaining system, yet shares all the virtues of its near-neighbour Austria. Japan too is often mentioned as an exception. However, although bargaining is mainly conducted at the plant or enterprise level, it is strongly coordinated by the 3 major trade unions during the annual "Spring Offensive".. On the basis of Tarantelli's definition, therefore, the Japanese system cannot be regarded as decentralised.

It is not being suggested here that variations in bargaining systems provide the sole, or even the most important, explanation for the observed differences in macroeconomic performance and levels of strike activity noted above. After all, apparent correlations do not amount to a causal theory. Nevertheless, there are good reasons for believing that for a country like New Zealand, with a moderate-to-high level of union coverage, a moderate level of industrial unrest, and deeply entrenched notions of comparative wage justice, the economic and social gains from a more decentralised wage fixing system may not be great. This does not mean that we should abandon the quest for reform, or that we should strive instead for a Swedish-type "solidaristic wages policy" (Robinson, 1974) in which wage equalisation is sought irrespective of productivity levels or a firm's ability to pay. Rather it suggests that we should proceed with caution and without exaggerated optimism. It also suggests that it would be wise to focus our energies on reforming those aspects of the existing system which are most obviously inefficient and conflict-producing. One such feature is the occupational character of our union and bargaining structures.

The harmful consequences of an occupational, as opposed to an industry-based, system of wage determination are well known and do not need to be laboured. Amongst other things it leads to the pursuit of narrow, particularistic concerns, it generates additional tension and conflict in the workplace, it confronts larger employers with a multiplicity of competing bargaining groups, and it prevents ability-to-pay factors from playing a significant role in wage determination, certainly at the national award level. Industry-based bargaining, on the other hand, generally avoids these problems. Furthermore, if it is married with an element of enterprise bargaining, as is the case in Austria, or with flexible payment systems it provides scope both for a degree of central coordination (when this is deemed desirable for macroeconomic reasons) and for a measure of wage flexibility.

There is but one difficulty. Unfortunately it is serious. Experience suggests that industrial relations reform, especially in the absence of a war, revolution or dictatorship, can be time consuming and expensive (i.e. in terms of the extra transaction costs and strike costs). It is perhaps salutary to be reminded that the Swedish central union organisation, the LO, voted in 1912 to institute the principle of industry-based unionism. It took some 60 years to implement this decision (Visser, 1983, p. 15). Similarly, the Norwegian LO agreed in 1923 to endorse industrial unionism, but even today, 62 years later, there are many small occupational unions (Visser, 1983, p. 15). In fact, although industrial unionism and industry-based wage bargaining is endorsed by most trade union confederations around the world, it has only been fully implemented in a few countries. Moreover, in only 2 cases, Austria and West Germany, was industrial unionism introduced speedily and without significant resistance from employers or workers. In both cases this occurred in the aftermath of World War II and the reforms were imposed by the occupying powers. In New Zealand perhaps the most that can be hoped for in the short term is the gradual diminution in the importance and coverage of national awards as paid-rate documents, a greater reliance on minimum wage legislation to protect the lower paid, the development of more flexible second-tier bargaining, and some agreement on new composite wage settlements in certain sectors. However, even these developments could prove something of a mixed blessing, as may become apparent during the next few wage rounds. 


\section{The 1985-1986 wage round}

In considering the prospects for the 1985-86 wage round it is important to bear in mind the unique character of the present wage fixing environment. To start with, this is the first time since the emergence of annual wage rounds in the late 1960s that bargaining is likely to proceed in the absence of a General Wage Order (GWO) before, during or after the round. Second, bargaining will take place in the aftermath of an extended wage and price freeze, a significant devaluation, and the most sustained period of economic growth since 1972-1974. Third, it will be the first "normal" round since 1981-1982, and may yet prove to be the first period of collective bargaining for well over a decade which has been conducted in the absence of formal guidelines, legal restrictions, or threats to impose statutory controls. Finally, the round will take place in the context of extensive tripartite consultations, various reforms to the wage fixing system in the private sector, significant taxation and social policy changes, and a governmental determination to maintain a firm, non-accommodating monetary policy.

In terms of its overall economic strategy, the Labour Government has 2 principal objectives on the wages front: firstly, to ensure that the growth of average earnings in the year to September 1986 is relatively restrained - which means no more than about 12 percent (Treasury, 1985B, p. 6); and secondly, to ensure that there is a much greater variation in settlement levels than has been the case during the past decade. This applies to both national awards and second-tier agreements.

What are the prospects of these aims being fulfilled? Those who take an optimistic view rest their case on one or more of the following considerations:

(1) the Government's pursuit of tight monetary and fiscal policies;

(2) the absence of a GWO;

(3) the impact of the recent economic policy changes on the degree of employer resistance to pay claims;

(4) the loyalty of the union movement to the Labour Government, as evidenced by the restraint exercised during the 1984-1985 wage round;

(5) the changes to the wage fixing system as a result of the Wages Accord in September 1984 , in particular the introduction of voluntary arbitration;

(6) the positive impact of the planned tax cuts and social policy changes on real disposable incomes.

Point (1) has already been dealt with the depth, so there is no need to repeat all the arguments here. As for point (2), it is doubtful, certainly on the basis of overseas experience, whether the absence of a GWO will prevent a substantial rise in wage rates. On the other hand, the evidence of the 1970s (Boston, 1984, pp. 299-300) suggests that if a GWO is granted in the absence of explicit restrictions on bargaining freedom the likelihood of excessive wage growth will be increased. With respect to point (3), it seems unlikely that the Government's recent measures to enhance business competition, such as the removal of some import controls and the deregulation of certain industries, will make a major difference to the level of employer resistance in pay bargaining in the short term. And, even if it does in particular cases, the occupational structure of wage determination in New Zealand will tend to mitigate the effects of this on actual pay settlements.

Clearly one of the most fascinating issues concerns the extent to which the political loyalties of the union leadership will lead them to exercise their discretionary power to restrain the size of settlements, point (4). There can be little doubt that this was one of the contributing factors to the "success" (i.e. in terms of securing relatively low settlements) of the 1984-85 wage round. However, it is improbable that political loyalties will count to the same extent in the immediate future. First, as is well known, there are now some serious strains in the relationship between the industrial and parliamentary wings of the labour movement. Second, union leaders may simply find themselves unable to prevent individual bargaining groups formulating and pursuing big wage claims. Lastly, it should be noted that political loyalty was neither the only, nor even the most important, 
reason for the moderation shown in the 1984-1985 round. Other factors included the compressed, almost artificial nature of the round, the economic "crisis", the "spirit of consensus", the Government's overly optimistic inflation forecasts, the introduction of Family Care, and the decision of most unions to defer many of their bargaining demands until the 1985-1986 round. Most of these conditions no longer apply.

With regard to point (5): it is difficult to assess at this stage what impact the introduction of voluntary arbitration in late 1984 will have on the overall spread and average level of award settlements during the next few wage rounds. It is certainly possible, however, that voluntary arbitration will become, as Kirk suggests, "one of the more significant elements of wage fixing in the future" (Kirk, 1985, p. 4). As it stands, the new procedures enable either employers or unions to refuse to take disputed claims to the Arbitration Court. This provision is unlikely to affect the bargaining behaviour of relatively powerful groups, such as the main trend-setting groups, since they have displayed a reluctance over many years to go to the Court. Nevertheless, it is probable that some employers will use the new provision against poorly organised and reasonably passive groups of workers in non-strategic sectors of the economy (e.g. clerical workers, shop employees, catering staff, cleaners, etc.). Should they do so, there is a distinct possibility that the award settlements of such groups will lag well behind those of more powerful unions and that traditional relativity relationships will be broken. This, of course, means that future wage rounds could witness a greater spread of pay settlements and a somewhat lower growth in average earnings than might otherwise have occurred. It could also result in the undermining of awards as paid-rate documents in certain sectors.

The final reason for optimism relates to the August Budget (point (6). The argument here is that by cutting taxes and improving welfare assistance the Government can "buy off" pressure for substantial wage increases. It is impossible to assess the impact of such a strategy until the details of the Government's package are known. However, it is clear that much will depend on (a) the actual magnitude of the tax cuts; (b) their timing; (c) their distributional bias, and (d) the willingness of the union movement to trade tax cuts for wage rises. To date the unions have been unsympathetic to such an approach (Brosnan, 1983). Whether this attitude changes remains to be seen.

Turning to the grounds for pessimism: What reasons might there be for expecting a significant short-term acceleration in the rate of wage inflation (i.e. to 15 percent or more)? In general it can be argued that fluctuations in money wages are influenced by 2 principal factors: (1) the relative power of unions and employers; and (b) the willingness of the various parties to exploit their power (i.e. the level of bargaining intensity).

The relative power of unions and employers obviously depends on a host of matters (e.g. organisational strength, the degree of solidarity, the level of output, the level of profitability, and labour market conditions). In the current circumstances most of the evidence points to the union movement being in a stronger bargaining position than 12 months ago, and possibly its strongest position since the mid-1970s. Record profits are being reported. Productivity has improved. Capital utilisation remains high. Exports are continuing to grow strongly. Private sector investment is buoyant. And, despite signs that economic activity has peaked and that a mild downturn has begun, business confidence remains at a reasonable level (New Zealand Institute of Economic Research, 1985). Equally significant, total employment has grown rapidly - by over 40000 in the year to March 1985, unemployment has fallen, and shortages of labour have been reported, especially for skilled and professional workers (e.g. medical staff, engineers, accountants, senior managers, economists, technicians, computer operators, tradesmen, electricians, police, armed forces personnel, chefs, etc.). Tight labour markets conditions of this nature will necessarily reduce employer resistance to large wage claims, notwithstanding attempts by the Employers' Federation to prevent "soft" settlements. The primary question, therefore, is whether the union movement chooses to exploit its current advantages to achieve substantial pay increases. At present this remains uncertain. Nevertheless, there are many reaons for expecting some escalation in the degree of union "pushfulness": 
(1) Historically, industrial unrest usually increases during an economic upturn, particularly if it has been preceded by a contraction of real wages. This happened, for example, in many countries including New Zealand during the late 1960s and early 1970s (Soskice, 1978), and is currently the case in Sweden.

(2) It would also appear, at least on the basis of the British experience of the early 1970 s, that strike activity rises in conjunction with changes to bargaining structures. To the extent that the 1985-86 round witnesses a further shift to wage bargaining at the enterprise level, one would expect there to be an upsurge in the number of stoppages. For example, bargaining groups will probably attempt to "try out" their employers. Also it is possible that "weak" employers will be targeted in order to secure favourable house agreements. Once concessions have been made, other workers in related trades or enterprises of a similar type will then seek similar wage rates and conditions of employment via horizontal relativity arguments. Such developments were a feature of the last major economic upturn in the early 1970s.

(3) Another factor concerns the impact of the freeze and the devaluation on real wages. In the 3 years to March 1985, real pre-tax ordinary time weekly earnings fell on average by 11.1 percent. Since then real wages have fallen even further. To be sure, the decline in real disposable incomes has been less severe (about 5.5 percent on average in the 3 years to March 1985), though for some groups it has been substantial (e.g. the third quintile has suffered a fall in real disposable incomes of 9.4 percent in the 3 years to March 1985) (Department of Statistics, 1985). Those who believe in the inevitability of a wage rebound following a period of statutory controls and realwage cuts (and this includes most monetarists) and those who hold to some kind of target real-wage hypothesis (and this includes many post-Keynesians) must, it seems, expect a significant acceleration in money wage growth in the near future. If they are proved wrong, some revision of the respective theories may well be necessary.

(4) A further reason for expecting an increase in bargaining intensity relates to the fact that the 1985-86 round will be the first "normal" period of bargaining for many years. Consequently, most groups will have long bargaining agendas - the restoration of lost relativities, the resolution of anomalies, the restructuring of awards, improvements in working conditions (health and safety provisions, etc.), new and improved fringe benefits, additional allowances, and so on. Moreover, many groups will probably be willing to take their time in order to achieve the best possible deal. This means, in effect, that resort to strike action (or strike threats) could become an integral part of their bargaining strategy.

(5) Yet another matter concerns the prospects for inflation during the next year. The Treasury is predicting an annual rate of 12 percent by March 1986, presumably with the rate falling steadily after that until the introduction of GST (Treasury, 1985B, p. 10). However, this is contingent, amongst other things, upon a moderate wage round and a reasonably stable exchange rate. In the absence of one or other of these conditions (or both), the rate could be higher. Given the current degree of uncertainty surrounding the future path of prices, some intensification of bargaining intensity can be expected.

As an incidental point, it would seem that the Treasury's inflation forecasts have been remarkably optimistic. In late 1984, for example, it was assumed that the rate of inflation in the year to March 1986 would be about 6 percent (Treasury, 1985A, p. 2) and that the 1985-86 wage round would be no higher than the 1984-85 round. To be sure, the 6 percent figure has now been revised upwards to 12 percent. But even this prediction seems low, especially in the light of the recent 5.1 percent June quarter. Indeed, for the forecast to prove accurate it will mean that the rate of inflation will have to slow more rapidly than occurred during the first 9 months of the wage-price freeze implemented in June 1982. This is very doubtful (unless the exchange rate appreciates considerably in value).

(6) Finally, there is a possibility of a widespread wage push being triggered by large (i.e. 
15 percent plus), well publicised, and destablising settlements occurring during the early stages of the round. The Higher Salaries Commission will be reporting in September and it is likely to increase the salaries of those under its jurisdiction by 20-30 percent (which is the reported level of wage drift in the upper echelons of the private sector since April 1981). Pay rises of this magnitude are bound to have psychological effects, if not some political ramifications. Quite apart from the report of the Higher Salaries Commission, destabilising settlements could come from a wide range of bargaining groups whose labour is currently in short supply. If other groups then seek to re-establish their lost relativity, which is likely, conflict over income shares could become both widespread and intense. It is worth remembering that this is precisely what happened in New Zealand (1969-1970) and in Australia (1981-1982), to mention only a few instances.

To sum up: unless there is an unexpectedly sharp contraction in economic activity during the latter half of 1985 similar to that which occurred in 1982, the bargaining power of organised labour during the 1985-86 wage round should remain above the level of the past 3-4 years. In addition, past experience indicates that, given the current economic context, there could be an upsurge in bargaining intensity. Indeed, the only reasons for thinking otherwise relate to the union movement's political affinity to the Government and the positive effects of the planned tax and welfare changes on real disposable incomes during 1986.

As it stands, real wages and real disposable incomes must be near to their minimum acceptable levels. It is difficult to envisage, therefore, that further cuts in living standards will be readily tolerated. This being so, one would expect that most union negotiators will accept nothing less in the coming round than an amount equivalent to the rate of inflation during their 1984-1985 contract period (of 10 months). This could mean national award increases averaging 12-14 percent plus wage drift of 1-2 percent, that is, unless employers are able to demonstrate an unprecedented level of solidarity or refuse to allow disputed claims to go to arbitration. Such an outcome, of course, would not be welcomed by the Government. It would mean higher inflation in the short term and almost certainly higher unemployment in the medium term. Moreover, if the exchange rate falls to compensate for the loss of international competitiveness, short-term inflation rates will go even higher. And, if the exchange rate does not adjust, perhaps because of high interest rates, we could have a rather unpleasant, though less dramatic, replay of the British experience in 1980-82.

What is to be done? Assuming that the 3 parties fail to reach an agreement on a wage guideline, the Government has a range of options. Unfortunately they are all potentially unattractive:

(1) The first possibility would be to put the clock back and seek to restrain wages by means of non-market instruments (i.e. statutory controls). Such a strategy, however, is likely to arouse fierce opposition, and may simply forestall an inevitable adjustment problem. In short, statutory controls could well prove ineffective and inefficient.

(2) A second option would be for the Government to announce a wage guideline unilaterally, as National did on several occasions before the freeze and as the Callaghan Government did in both 1977 and 1978 . The difficulty here is that if the guideline is "unrealistic" (e.g. in current conditions under 10 percent) it will simply be ignored. And yet if it is "realistic" it will probably make little difference to the actual level of wage settlements.

(3) An alternative possibility would be to announce a guideline and then try and defend it through selective measures of one kind or another (e.g. price controls, tax penalties, regulations, the "manipulation" of government contracts, the abolition of the Higher Salaries Commission, or a delay to the implementation of its report, etc.). But such a strategy is likely to be messy in administrative terms, is bound to cause distortions to relative prices, and on past experience (1979-1980) is likely to generate very considerable levels of strike activity (Boston, 1984, pp. 201-210).

(4) The final option is to avoid guidelines, legal restrictions and sanctions, and rely in- 
stead on a mixture of moral suasion, jaw-boning, tax compensation and market mechanisms (i.e. monetary policy and competition policy), with a bit of hope and prayer added for good measure. In accordance with this scenario the primary aim must be to ensure that the early wage settlements, and particularly the main trendsetting awards, are kept as low as possible (i.e. nearer to 10 percent than to 15 percent).

Should the more-market approach fail to keep the growth of average earnings to a level consistent with the Government's monetary objectives, it looks as if we will simply have to put up with higher short-term inflation and more unemployment. This is unpalatable, but it may turn out to be unavoidable. For to accommodate a significant wage push by pursuing a lax monetary policy will merely delay the hour of reckoning. As Max Corden has lamented, if wages go through the roof "the real choice for the government is deflation and unemployment now or deflation and unemployment later" (Corden, 1982, p. 113). It must be sincerely hoped that the Labour Government is not obliged to make such a choice.

\section{Conclusion}

Some 14 years ago the New Zealand Monetary and Economic Council made the following observation:

It is very much easier to analyse the reasons why the processes of income determination can cause an excessively rapid spiral of costs and prices, even in conditions of relatively depressed demand, than it is to find remedies for the problems concerned (Monetary and Economic Council, 1971, p. 117).

Despite a good deal of experimentation since the early 1970s, both here and overseas, we are still no nearer to finding painless methods of disinflation. The Labour Government is now embarking on a new approach to the control of inflation, new at least for this country. If it proves successful, in the sense that we are able to over the next few years to avoid the usual transition costs of higher unemployment and lower real output, it will be a remarkable achievement. If it proves unsuccessful, it will indicate that we live in a cruel world where the choice is not so much between market solutions and non-market solutions, but between market failure and non-market failure. Which outcome is worse is not an easy matter to resolve. For those who suffer the resultant indignity of unemploy. ment, the effects are the same.

\section{References}

Boston, J (1984) Incomes Policy in New Zealand, 1968-1984 Wellington, Victoria University Press for the Institute of Policy Studies.

Brittan, S and Lilley, P (1977) The Delusion of Incomes Policy London, Temple Smith.

Brosnan, P (1983) Tripartite Wage Agreement: A Feasible Objective? In Buckle, R A Inflation and Economic Adjustment: Proceedings of a Seminar Department of Economics, Victoria University of Wellington.

Buiter, W H and Miller, M H (1983) Changing the Rules: Economic Consequences of the Thatcher Regime Brookings Papers on Economic Activity 2: 305-365.

Cagan, P and Fellner, W (1983) Tentative Lessons from the Recent Disinflationary Effort Brookings Papers on Economic Activity 2: 603-608.

Corden, W M (1982) The Wages Push and Macroeconomic Policy: The Dilemmas Ahead The Economic Record 58: 111-117. 
Davies, G (1985) The Pound in Your Pocket New Statesman 25 January.

Department of Statistics (1985) Real Disposable Income Measures and Related Series March Quarter 85/109, Wellington.

Douglas, R O (1985) Budget 1985 Wellington, Government Printer.

Flanagan, R Soskice, D and Ulman, L (1983) Unionism, Stabilisation and Incomes Policy Washington DC, The Brookings Institution.

Gordon, R J (1983) Why US Wage and Employment Behaviour Differs from that in Britain and Japan The Economic Journal 92: 13-14.

Jones E (1983) Monetarism in Practice Australian Quarterly 55: 433-445.

Kirk, A (1985) Incomes Policy and the Wage Round Paper for IPS/IRC Seminar on Incomes Policy and the 1985-86 Wage Round, Victoria University of Wellington.

Kozomzay, V (1982) Credibility and Demand Restraint American Economic Review: 86-89.

Layard, R (1982) Is Incomes Policy the Answer to Unemployment? Economica 49: 219:239.

Llewellyn, D T (1980) Can Monetary Targets Influence Wage Bargaining? The Banker 130: $49-53$.

McCallum, J (1983) Inflation and Social Consensus in the 1970s The Economic Journal 93: 784-805.

Meade, J E (1982) Stagflation: Volume I: Wage Fixing London, George Allen and Unwin.

Monetary and Economic Council (1971) Inflation and the Labour Market Report No. 22, Wellington.

New Zealand Employers' Federation (1985) Statement to the Tripartite Wage Conference 12 June.

New Zealand Institute of Economic Research (1985) Business Opinion 30 June.

OECD (1985) Economic Surveys: New Zealand Paris, OECD.

Perry, G L (1983) What have we learned about disinflation? Brookings Papers on Economic Activity 2: 587-602.

Robinson, D (1974) Solidaristic Wage Policy in Sweden Paris, OECD.

Schelling, T C (1982) Establishing Credibility: Strategic Considerations American Economic Review: Papers and Proceedings: 77-80.

Schmidt, M G (1984) The Politics of Unemployment: Rates of Unemployment and Labour Market Policies West European Politics 7: 5-24.

Soskice, D (1978) Strike Waves and Wage Explosions, 1968-70: An Economic Interpretation. In Crouch, $\mathrm{C}$ and Pizzorno, A (Eds.) The Resurgence of Class Conflict in Western Europe Since 1968: Volume 2: Comparative Analyses London, Macmillan.

Tarantelli, E (1983) The Regulation of Inflation in Western Countries and the Degree of Neo-Corporatism European University Institute, 154/83 (SSCP 14).

Taylor, J B (1982) Establishing Credibility: A Rational Expectation's View Point American Economic Review: Papers and Proceedings: 81-85.

The Treasury (1984) Economic Management Wellington, Government Printer.

The Treasury (1985A) Three-Year Fiscal Projections 1985/86-1987/88 Wellington, Government Printer.

The Treasury (1985B) The State of the New Zealand Economy Briefing Paper for the 1985 Tripartite Wage Conference. 


\section{Jonathan Boston}

Visser, J (1983) The Unification and Centralisation of the Trade Union Movement: A Comparison of Ten Countries European University Institute 163/83 (SSCP 23).

Weitzman, M L (1985) Profit Sharing as Macroeconomic Policy American Economic Review: Papers and Proceedings: 41-45. 